\title{
ЯЗЫКОЗНАНИЕ
}

\author{
UDC 811.41
}

\section{Techniques and Practices of Speech Expression in Arab Diplomatic Communication}

\author{
E. K. Akhmatshina ${ }^{1}$, K. Yu. Demidova ${ }^{2}$, A. Yu. Bykov ${ }^{1}$ \\ ${ }^{1}$ St. Petersburg State University, \\ 7-9, Universitetskaya nab., St. Petersburg, 199034, Russian Federation \\ 2 National Research University Higher School of Economics, \\ 16, ul. Soyuza Pechatnikov, St. Petersburg, 190121, Russian Federation
}

For citation: Akhmatshina E. K., Demidova K. Yu., Bykov A. Yu. Techniques and Practices of Speech Expression in Arab Diplomatic Communication. Vestnik of Saint Petersburg University. Asian and African Studies, 2021, vol. 13, issue 1, pp. 103-118. https://doi.org/10.21638/spbu13.2021.107

The article is devoted to analysis of the techniques and practices of speech expression in Arab diplomatic communication through the example of speeches made by Arab diplomatic corps representatives and politicians at various UN venues. Original texts of speeches made by Permanent Representatives of Arab countries at the UN concerning the situation in the Middle East were chosen as the material for the study. The time frame covers the period from 2011 to 2018. The UN's multimedia resources are one of the largest platforms for diplomatic dialogue open to the general public. Due to the intensification of relations between Russia and the Arab countries, it is necessary to identify the specifics of Arab diplomatic communication, as the speaker's statements are not intended to express his or her own attitude and assessment, but the attitude of the state he or she represents. When analyzing the texts of speeches by diplomatic corps representatives in general, we observed the interpenetration and mutual influence of several types of language styles, which depend on the specifics of the issue under discussion: officialese style, inherent in diplomatic correspondence, and publicistic, which is found in public speeches. The intermingling of styles undoubtedly affects both the lexical and syntactic weight of the texts in a statement. In turn, Arab speakers cannot remain emotionally indifferent to the problems of their region due to the difficult political situation in the Middle East. For this reason, we noted not only a regular deviation from diplomatic speech standards, primarily the abundance of emotionally evaluative vocabulary in the texts of their speeches, but also special strategies for constructing texts that help to have a certain effect directed at listeners and opponents - expression. Among the most commonly used methods of speech expression, we have identified repetition, cohesion, convergence and the effect of defeated expectancy. By means of analysis of expressive syntaxes we studied the specifics of the use of these methods of speech expression at the

(C) St. Petersburg State University, 2021 
level of usual-clichéd Arabic text and highlighted the specifics of tapping this speech strategy in the language of Arabic diplomacy.

Keywords: modern standard Arabic, language of Arabic diplomacy, speech expression.

\section{Introduction}

The purpose of this research is to study the techniques and practices of expression in Arab diplomatic communication at the level of text organization of speakers' statements. The relevance of the paper is dictated by the fact that there are few works in modern linguistics devoted to the analysis of diplomatic discourse and oral diplomatic communication in general and the means of expression in it in particular.

For modern linguistics, studying the specifics of a diplomatic language in its cultural and historical environment is valuable. Despite its static character, the diplomatic language develops following changes in the foreign and domestic policy of states, as well as changes in the international arena. A special category in the characteristics of the diplomatic language is occupied by public speeches of the diplomatic corps representatives. Due to the specifics of their activities, they are forced to speak about the position of their state in front of an audience, given the limitations imposed on them by the peculiarities of the diplomatic sphere of communication and the diplomatic language. Diplomatic communication, as well as any oral communication, is characterized by strategicity. An oral strategy is "a set of speech actions aimed at achieving a communicative goal" [1, p. 54]. It requires a range of defined tactics and strategies to achieve a predictable result in, for example, negotiations.

In controversial political situations, such tactics are used by diplomats to create "uncertainty" and ambiguity in order to be able to have, in the words of the researcher H. Trabelsi, an "emergency exit" regardless of the course of events [2, p. 4].

As in any communication, the sender of a message wants to convey as much information as possible and be understood, so he or she resorts to a variety of stylistic devices that increase the impact on the audience. Furthermore, despite the diplomatic language's tendency for objectivity and impersonality, a representative of the diplomatic corps cannot avoid expressing the assessment and attitude of his or her state towards the described event. In this case, we are talking about expressivity in the diplomatic language.

\section{Methodology}

In order to analyze strategies for displaying expressivity in Arab diplomatic communication, we have set ourselves the task of looking at a collection of the most common syntactic strategies for displaying expression in the texts of speeches made by members of the Arab diplomatic corps.

The study was based on 60 public speeches by members of the diplomatic corps and politicians from Arab countries in various United Nations bodies. All the speeches were dedicated to the situation in the Middle East, which includes a diverse range of issues: the humanitarian situation in the region, assistance to victims of the war, discussion of resolutions on the Syrian crisis, etc. The time frame covers the period from 2011 to 2018, i. e. from the beginning of the Syrian crisis. 
The UN was chosen because it is one of the largest platforms for diplomatic dialogue and is open to the general public. In addition, Arabic is one of the six official working languages of the UN, which can guarantee the originality of all texts in Arabic. According to General Assembly Resolution 3190, published in 1973, Arabic has become the official language of this organization and since then all documents have been "automatically" translated into Arabic.

The main method used is the principle of contrastive analysis, which allows the application of certain comparison parameters (the method of linguistic interpretation).

\section{Discussion}

The relatively modest number of researches is dedicated to the analysis of the phenomenon of expression in Arab public speech, especially compared to other areas related to the development of the modern Arabic language. According to E. N.Haigadachnaya, a researcher of expression in politicians' speeches, "Effective public speech is maximally deautomated, personally oriented, extremely expressive and emotional" [3, p. 7]. This understanding also applies to the speeches of politicians and diplomats, but it is worth noting that the institutionality of the environment and the peculiarities of the diplomatic substyle, which is typical for diplomats' speeches, noticeably limit the space for free emotional self-expression. Diplomatic speech is less emotional and expressive, but it also tries to achieve maximum impact on listeners, and speakers can also express their attitude towards the subject they are speaking about. In such cases we can observe the expressivity of text and speech.

Linguistic manipulation strategies have now been developed to such an extent that they can significantly influence the behavior of the masses [4, p. 84], the outcome of negotiations or voting, for example, in international organizations for a resolution. In order to achieve positive results, political and diplomatic representatives use different language techniques and practices of expression as a tactic of manipulation. Scientific research shows that in any act of speech communication, communicators pursue certain non-verbalized goals, which ultimately affect the actions of the interlocutor [5].

Often, both in domestic situations and in scientific research, there is kind of diffusion of the concepts of "expression" and "expressivity", so it seems necessary, firstly, to clarify the differences in the meaning of these definitions.

The concept of "linguistic expression" is not fully and uniformly defined in general theory [6, p. 8]. In dictionaries one can find the following definitions: «Expression is the expression of feelings, experiences, expressiveness» [7]; "expression is the expressiveness, bright, significant expression of feelings, moods, thoughts" [8]; "expression is what gives expressive power to something that makes that something expressive" [9].

According to the Linguistic Encyclopaedic Dictionary, edited by V.N. Yartseva, expressivity is "a set of semantic and stylistic features of a language unit that ensure its ability to serve in a communicative act as a mean of subjectively representation of the speaker's attitude to the content or receiver of the speech" [10].

In other words, expressivity is a semantic-stylistic category that represents the speaker's emotional and evaluative attitude, while expression is "an increased expressiveness of speech that consists of additional emotional and evaluative information" [11, p.3]. The difference lies in the focus of the concept: expression is a linguistic characteris- 
tic of speech, while expressivity is a characteristic of the agent's attitude towards reality, which appears at different levels of language. In this paper, expressivity will be used to describe the relationship of a political or diplomatic figure to the issue under discussion, while expression will be used to describe the degree of evaluativity and emotionality of a speech.

However, there are researchers who look at this concepts' distinction differently. For example, the French linguist G. Guillaume in his work "Principles of Theoretical Linguistics" relates the concept of "expression" to expression and "expressiveness" to expressivity, with "expression" referring to an established aspect and expressiveness to improvisation [12, p. 87].

Russian researcher L. B. Morgoeva believes that expression is "an effect that produces a statement which contains information coming exclusively from a speaker. He or she passes judgment, inference or thought itself". She sees expressivity as synonymous with expressiveness [13, p. 17] and defines the phenomenon as follows: "Expressivity is the ability or characteristic of any semantically organized unit of language or group of units to activate their potential capabilities (additional meanings) to achieve the best effect. And expression is the result of activating this capability" [13, p. 20]. Thus, expression, as understood by L. B. Morgoeva, refers to the way the recipient perceives information, while expressivity refers to the stylistic and semantic features of separate language units.

It is worth noting that expressivity is a characteristic of units at all levels of the language: at the phonetic level, for example, these are phonologically irrelevant changes in sounds, accent and intonation means. Morphological means include word formation and hypocoristic and pejorative affixes. Lexical expressive means cover layers of words that have an evaluative component in addition to their presentive-logical meaning, as well as interjections and emphatic particles. On the syntactic level, expressivity is signified in change of the usual word order, use of elliptical constructions, repetitions, etc. [10, p. 687]. In this paper we will elaborate on the lexical level of analysis of public speeches, but we will not neglect the other levels.

The specificity of Arab communication is the coexistence of two monogenetic but typologically unidentified communication systems: bookish-written literary system and spoken dialectal one [14, p. 74]. Since written and spoken styles mix in public speeches, it can be assumed that the two communication systems may also mix. Despite the official nature of the environment and the need to speak the language accepted in a given society, there is a shift away from the Modern Standard Arabic, which can also be an indicator of expressivity. Along with this, the alternation between the Modern Standard Arabic and Arabic dialects can manifest itself on both phonetic and lexical levels.

Expression of a word frequently is layered on its emotionally evaluative meaning, so it is often impossible to distinguish between the two concepts, which allows us to talk about emotionally expressive vocabulary.

The emotionally expressive colouring of a word is often influenced by its meaning, for example, words such as fascism (الفانشية), repression (القعع) and wastefulness (الاسر اف) received a sharply negative evaluation. In addition, different meanings of the same word may have different stylistic colouring: neutral: الوحيدون تحقيق ربح في هذا الارض تخلي هم التجار

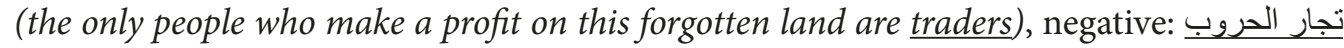
هكذا يحتركون السلع الغذائية ويتحكمون بالدلار (those who make money from wars: they speculate on food products and own dollars). 
The development of expressive shades in the semantics of a word is also facilitated by its metaphorisation [15, p. 81]. It is possible that stylistically neutral words used in a figurative sense receive expression. The stylistic colouring of words is also greatly influenced by context.

The source of lexical units for creating expression can be scientific and technical terminology and special vocabulary [11, p.7]. With figurative conceptualization (metaphorisation, metonymisation, etc.), the general meaning of terms acquires an additional semantic load on a stylistic level. The expressivity of this type of terms does not become a permanent phenomenon; it is occasional.

Other sources for language expressiveness may be occasionally used foreign language vocabulary. Although the diplomatic style belongs to the officialese style, the analysis of the speakers' speeches shows accumulations of conversational expressions. The use of historisms and obsolete vocabulary is also possible. The effect of their usage is based on comparing elements of the past with the present. Their main expressive function is to give negative evaluative meaning, often irony and a grotesque shade founded in hyperbole [10, p. 11].

Means of expressivity's expression include the already mentioned metaphor (مجاز (استعارة), which in political and diplomatic discourse is used as a ploy to attract listeners' attention [4, p. 85], metonymy, simile, allusions, quotations, catch phrases, proverbs and sayings.

It should be noted that in Arabic, expressivity is more based on speech techniques using words in their direct, non-transparent meanings: various repetitions of synonyms and quasi-synonyms, reduplication of lexical units $[16, \mathrm{p} .21]$.

Metonymy (a literary device based on a certain association/similarity of two phenomena) is one way of pragmatic influence leading to a transformation of the world view existing in the consciousness of the receiver [4, p.86]. In political discourse, however, metonymy acquires a long-term (sustainable) image and is understood as "replacing phrase with a virtually similar term or concept". Metonymy (مجاز مرسل) is one of the most used methods in contemporary Arabic speech [17, p. 115]. For example, the Arab press speaks of UN peacekeeping forces as ارض الجوذ الزرقاء Egypt (literally: "land of the pharaohs"), عاصمة الامويين - Damascus (literally: "capital of the Umayyads") and others.

The metaphor in the Arabic language is less informatively loaded than in Russian. The motive for the metaphorical use of words is in most cases obvious, so this figure of speech does not have the same emotional impact on the recipient as in Russian language $[16$, p. 21].

Also, a class of metonymy, synecdoche, is widely used in Arabic discourse. The presence of expressive meaning often depends on the context. There are often "dead synecdoches" that have lost their emotional colouring, for example, القى كلمة - gave a speech (literally: "threw a word"), اكدت موسكو - Russia confirmed (literally: "Moscow confirmed").

The simile is used to emphasise some peculiarities of the object in the phase by comparing it with other phenomena.

The epithet also serves as one of the brightest figures of speech. Moreover, epithets are used, the meaning of which already has an evaluation, as well as strengthening the evaluation of which is created by a number of techniques, for example, by introducing a different style, etc.

Successful communication is not possible without appealing to the background knowledge of the audience. In this case, allusion is used. It is a special method of text pro- 
duction, which consists in correlating the content of the statement's text with a precedent fact (historical or literary) by mentioning this fact or including it in the text [4, p. 85]. In speeches by politicians and diplomats, allusions are often linked to historical or recent events, which were widely covered in the press and caused public resonance.

Quotes and catch phrases, proverbs and sayings are also often used. In order to give expressivity, it is possible to include phrasemes that have a certain evaluation. They can be divided into positive, negative and modal, which, depending on the context, carry either a positive or a negative evaluation.

Positive evaluated phraseological units are characterized by stability and regularity of the usage, while negative evaluated phrasemes are more frequently changed in order to increase their expressiveness [11, p. 13].

O.E. Chukhantsev, a Russian orientalist and Arabist, stresses a great number of repetitions' usage to make Arabic communication more expressive. In his work on expressive-stylistic resources of the Arabic language, he highlights several types of repetitions.

- Rhymed repetitions, which are copulative/composite combinations of words formed from a single model which semantics are similar to those of a single word.

- Notional repetitions, which consist in the correlation of two or more synonymous units or units belonging to the same conceptual or associative field.

- Reduplications, i. e. repetitions of independent words in a structural and semantical state of conjugation [16, p. 17].

Syntactic parallelism is one of the means of expressivity. It can be an anaphoristic to reveal the general topic of a statement, returning the recipient to the early decoded speech segment [18, p. 12]. Public speeches are marked by an emphatic order of words: each sentence begins with new information called rheme [18, p. 13].

The language of diplomatic documents is characterized by the presence of the traditional practices and techniques of expression, which speeds up the process of forming typical style of phraseological units and determines the presence of a certain number of archaisms.

Types of diplomatic text may also include texts for briefings and press conferences for the media, even though they may be considered oral rather than written forms of communication. However, because texts for speeches are often prepared in advance, we can classify them as a special type of oral-written text.

In our study we have focused on such types of diplomatic documents of an oral-written nature, as a statement made by a representative of the diplomatic corps or a politician in front of an audience at UN platforms and recording of diplomatic negotiations.

\section{Results}

\section{Expression of expressivity at syntactic level and at the level of Arab diplomatic text}

Studying the category of expressivity at the text level allows us to explore the mechanism of its creation in greater depth. Complex structural constructions of the sentence and the text make it possible to focus on certain information.

Increase in expressivity of a speech is often associated with the logical or emotional separation of the author's thought, created by the so-called "foregrounding" technique 
proposed by the researcher I. V. Arnold. "Foregrounding means ways of text formal organization that focus the reader's attention on certain elements of the message and establish semantically relevant relationships between elements of one or often more than one levels" $[19$, p. 61]. There are several types of foregrounding such as cohesion, convergence, the effect of defeated expectancy, repetition. I. V. Arnold herself notes that these types were also studied by M. Riffater, S. Levin and R. Jacobson on the basis of texts from fiction literature [19, p. 61-69].

\section{Features of cohesion linguistic strategy}

As mentioned earlier, cohesion is the appearance of similar elements in similar positions rendering the integrity to the text. This term was suggested by S. Levin in his work on poetry $[19$, p. 65]. This technique is used to generalise large segments of the text and to achieve its unity.

The cohesion manifests itself at all levels and on differently sized sections of a text. Similarity of positions is a syntagmatic category, so it can be syntactic or based on the place of an element in a speech chain. In addition, the cohesion can appear as a syntactic parallelism or an antithesis. Structural similarity can be traced back to morphological constructions, while semantic similarity can be retraced by analyzing the use of synonyms, antonyms, words bound by generic-specific relations and words belonging to the same semantic field.

This element is common to many of the speeches we have studied, for example in the speech delivered by the Permanent Representative of Egypt, Amr Aboulatta, at the $8105^{\text {th }}$ meeting of the UN Security Council, almost every paragraph begins with a similar syntactic construction [20]:

Egypt declares its rejection of...

Egypt reaffirms...

Egypt abstained from voting...

Egypt is trying to include...

Egypt reaffirms that...

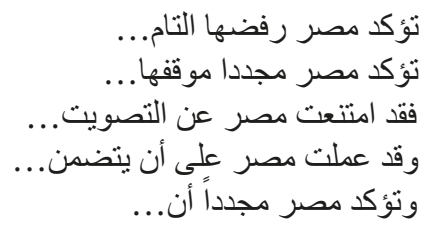

As we can see, these phrases contain a verb-predicate, a proper noun (the same) and an object, either direct or indirect. In this example, the cohesion is represented by syntactic parallelism. It is a structural similarity. Semantic similarity is achieved by the full equivalents of both the verb-predicate and the subject. Expressivity is thus achieved by rhythmisation of the text.

The cohesion can manifest itself on different levels: phonetic, morphological, syntactic. In the texts of speeches, cohesion occurs at the phonetic level. Analysis has shown that this technique can unite a couple of words close in terms of their phonetic appearance, but different in terms of their semantics when used side by side.

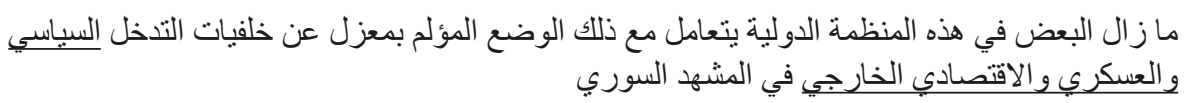

There are still Member States that are considering this difficult situation without taking into account the foreign interventionist, political, economic and military context in Syria.

The phonetic cohesion in this example is demonstrated by using four phonetically similar words, thanks to a similar formation model: three of the four words are trissyllable. 
The expressivity of the cohesion is achieved by rhythmisation of the test, which enhances its emotional impact.

$$
\text { و وخارجها شهود الزور، و عقدوا المؤتمر ات و الاجتماعات الرسمية وغير الرسمية داخل الأمم المتحدة }
$$

They fabricate false testimonies; they organise formal and informal conferences and meetings within and outside the United Nations.

The use of the same grammatical constructions emphasizes the author's emotionally evaluative attitude towards different public figures. By repeating them, the speaker seeks to enhance the expressive colouring of the phrase.

The following sentence may serve as an example for a syntactic antithesis:

$$
\text { فأن يكون لديك تصفية حسابات سياسية مع الحكومة السورية شيء، وأن تتخذ إجر اءات قسرية مرفوضة دولياً }
$$

It is one thing to settle political accounts with the Syrian government, but to resort to unacceptable international security measures against the Syrian people is another thing.

The lexical basis for this phrase is formed by contextual antonyms, i.e. words that are antonyms in a particular context. The syntactic basis is the parallelism of phrases. The antithesis forms a contrast that promotes expressivity and a clearer perception of thought $[11$, p. 146]. Parallelism is achieved by using the same grammatical forms.

Thus, the Arabic diplomatic discourse is characterized by cohesion on a syntactic level, but we can observe this type of language change throughout the text. The cohesion is used not only to link sentences, but also to link paragraphs. The value of this technique lies in its ease of use and ease of formation.

Examples of syntactic parallelism are often used, which increases the expressivity of the text and contributes to its connectivity. There is also cohesion on the phonetic and morphological levels.

\section{The features of conversion linguistic strategy}

The term "convergence" was introduced by French researcher M. Riffater. In today's world, this term has acquired a new meaning: in society there is interaction and interpenetration of various systems and elements of these systems, such as the newspaper and the Internet [21, p. 208]. As far as linguistics is concerned, I. V. Arnold, based on the works of M. Riffater, gives the following definition: "convergence is meeting in one place of a bundle of stylistic techniques involved in a single stylistic function" [19, p. 58].

In general, the use of this technique is typical for political communication due to its increased effect on listeners and the high percentage of manipulation ${ }^{1}$. However, because of the similarity of political and diplomatic communication functions, we can observe convergence in diplomatic texts, although less frequently. It is worth considering during the analysis of convergence that audiovisual factors should also be taken into account, as often intonation, gestures and facial expressions can have a significant impact on listeners.

${ }^{1}$ See also, for example, K. G. Borisenko's research "Stylistic Techniques as a Mean of Strengthening the Pragmatic Effect of the Text", based on the example of B. Obama's election speeches. 


$$
\text { و على هذا الأساس وجهت جامعة الدول العربية دعوة لهذا المجلس من أجل اتخاذ التدابير الحاسمة... }
$$

For this reason, the League of Arab States urged the (Security) Council to take strict measures...

In this sentence we see several stylistic techniques and practices, but their expressive colouring is not very expressed: inversion (the first place is the adverbial construction for this reason وعلى هذا الأساس), metonymy (transferring the name of political figures to the

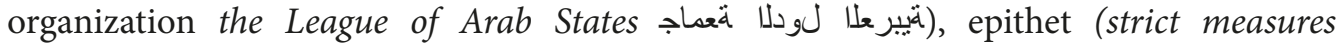

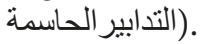

ألبس التصريح السياسي لبعض قادة الدول الأعضاء في هذا المجلس ووزراء خارجيتهم بأن الرئيس

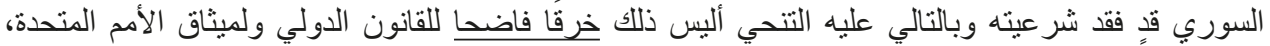

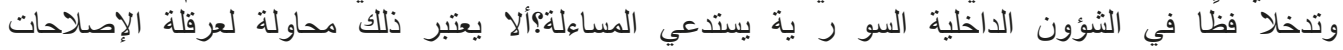

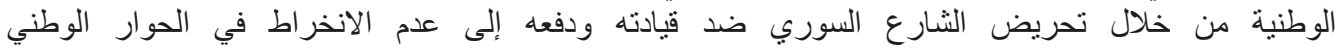

Aren't the political statements made by some of the leaders and foreign ministers of the countries represented on the Council that the Syrian President has lost his legitimacy and therefore should leave flagrant violation of international law and the United Nations Charter? Is that not a blatant interference in Syrian internal affairs and a reason to ask questions? Isn't that inciting the Syrian people to take to the streets and speak out against the legitimate leadership of Syria tantamount to trying to obstruct national reforms?

In the above example, convergence is presented at several levels. Firstly, at the syntactic level, there are rhetorical questions and syntactic parallelism. On the lexical level there is a metaphorical epithet (flagrant violation خرقا فاضح). In addition, the text contains semantic gradation and an abundance of emotionally evaluative vocabulary.

All of the above mentioned practices have the same stylistic function which is to have the maximum impact on the audience by showing the inconsistent and unfair behaviour of some UN Member States towards Syria.

An expressive payload that contains convergence can make the passage we described the culmination of the whole performance. Bashar Jaafari, Permanent Representative of Syria to the United Nations, condemns the behaviour of other states and achieves a sharp negative evaluation by enumerating facts and rhetorical issues, which resolves into gradations [22].

$$
\begin{aligned}
& \text { إن دولة الإمار ات تشعر بالقلق الثديد إز اء العنف والعنف المضاد في الأر اضي الفلسطينية المحتلة، و غياب الحل }
\end{aligned}
$$

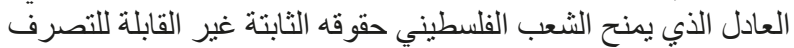

The United Arab Emirates is gravely concerned about the violence and counter-violence in the occupied Palestinian territories, and the absence of a just solution that grants the Palestinian people their inalienable rights.

In this example, convergence is created by stylistic techniques such as inversion, epithet (deep concern القلق الثديد), repetitions (violence العنف), special politological vocabulary (inalienable right حقوقه الثابتة غير القابلة للتصرف).

All these practices in their interaction allow the speaker to underline the position of his country and by using the terminology he also turns to global political practice for the protection of human rights. Thus, he draws attention to the two-faced policy of states towards the Palestinian people: human rights in other states are respected, according to the speaker Jamal Al-Musharrakh [23], while they are ignored in Palestine. 


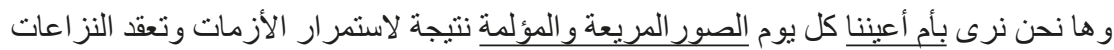

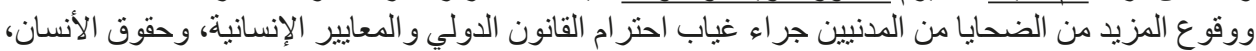

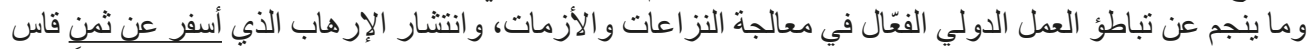

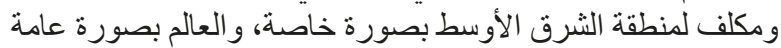

Every day we see with our own eyes the terrible, heartbreaking results of these crises and their intensification, as well as non-respect for international law and human rights. The international community today does not keep pace with events on the ground, and that has given rise to the spread of terrorism. The Middle East, as well as the world in general, is consequently paying a high price.

In the above sentence, convergence manifests itself in the following stylistic strategies: corroborative structures (with our own eyes بأم أعينتا), evaluative epithets (terrible and heartbreaking pictures الصور المريعة و المؤلمة), phraseme (pay a high price أسفر عن ثمن قاسم).

In this example, convergence was chosen by the author to attract attention of listeners by using a large number of epithets describing the plight of the Middle East and the inability of the global community to influence the situation. In addition, a large number of homogeneous grammatical constructions set a certain rhythm for the performance, which helps to convey information.

Convergence strategy is not very common in Arab diplomatic communication, as it requires careful preparation and a lot of time to create. It is mostly used at the culmination of a speech, when the message is critical to the speaker. Moreover, we have seen convergence that gives little or no expressivity to the text, which is the result of the elements used in it. On the one hand, we see an abundance of different stylistic techniques, but on the other hand, these techniques are expressively weak elements, such as "dead" metaphors and clichéd epithets. Convergence practices are most often used by representatives of Syria when it comes to the state of affairs in their country, as they are most appropriate for the emotionality of the statement.

\section{Expressive character of the effect of defeated expectancy}

Predictability or unpredictability of an element in a text is stylistically relevant. The type of foregrounding "the effect of defeated expectancy" is based on this principle. The essence of the effect of this technique is as follows, as I. V. Arnold explains: continuity, linearity of speech means that the appearance of each individual element is prepared by the preceding ones. In this connection, the transitions from one element to another are almost invisible, and the consciousness seems to glide on the information it receives. However, if elements of low probability appear against this background, a continuity disorder occurs, which acts like a push: unprepared and unanticipated action creates resistance to perception, overcoming this resistance requires effort from the reader or listener, and therefore he/she is more strongly influenced by it [19, p. 65].

This practice is typical to the language of politics, as it is characterized by the intention to have the greatest impact on the recipient [11, p. 160]. Contrast manifests itself at different levels. On the lexical level it can be the author's use of archaisms or neologisms, the use of an oxymoron or periphrasis, or the use of vocabulary in an "unexpected" context. On the text level it could be a violation of logical sequence [24]. 


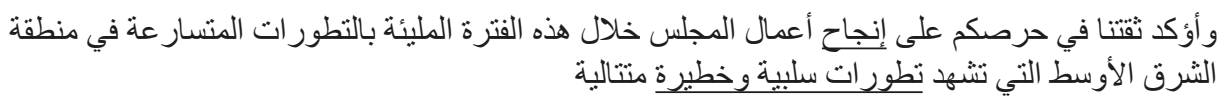

We are confident that the work of the Council will be successful in this period of escalating developments that are having a serious and negative effect on the Middle East.

In this example, the effect of defeated expectancy is achieved by using the positive evaluated word in the first part of the sentence in contrast to the negative content of the second part of the phrase. After mentioning the word انجاح (success), listeners wait for an explanation of this concept in a positive way, but the speaker uses expressions such as (escalation) and خطيرة وسلبية تطورات (serious and negative consequences). This technique is used at the beginning of the speech to focus the recipient's attention on the problem to be discussed later.

إضافة إلى مو اجهة تهديدات التنظيمات الإرهابية التي اتخذت من المنطقة مرتعا لنشر نفوذها و أنشطتها.

It also has to confront the threat of terrorist groups, which have made it a fertile ground for spreading their influence.

In this case, we see the same contrast as in the previous example, only the negative evaluated part goes first and then the positive evaluated part. When using the word (fertile ground), the recipient associates it with something good because of the positive connotation of the word "fertile", but before that the speaker describes the threats posed by terrorists. Once again, this contrast makes the listener pay attention to further information.

Lexically, the "effect of defeated expectancy" can be achieved through using neologisms, historisms, foreign language vocabulary and the violation of lexical compatibility. However, as mentioned earlier, these lexical units are rarely used in Arabic diplomatic communication. Because of this fact, the strategy of effect of defeated expectancy functions on the syntactic or text level. It is particularly common at the beginning of a speech because of the speaker's intention to immediately draw the audience's attention to the problem being discussed.

\section{Stylistic repetition strategy to enhance text expressivity}

Repetition is widely used in Arab diplomatic communication as a linguistic strategy of representation the intensity of expressivity. According to I. V.Arnold's definition, "Repetition is a figure of speech consisting of the repetition of sounds, words, morphs, synonyms and syntactic constructions under conditions of a sufficiently tight row" [19, p. 244]. The distance between repetitive words may vary, but is sufficient for the reader to notice them.

In the text, repetitions can perform various functions: streamlining the text, increasing the expressivity of the text, giving the text irony or sarcasm, etc. Often, repetitions are used in a mixture with other types of foregrounding, for example, as part of the convergence [25].

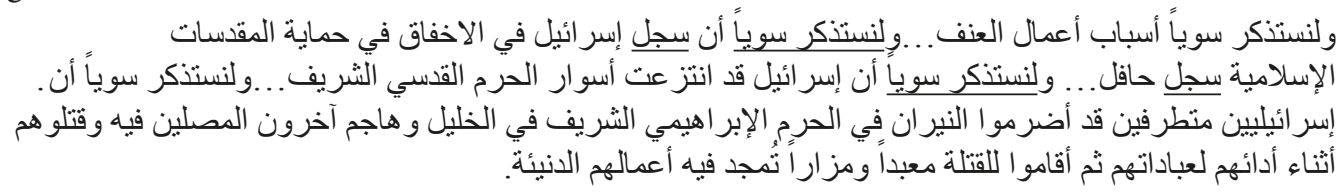


Let me remind you of the reasons behind the violence... Let us not forget that Israel is not in a position to protect the holy places of Islam ... We must also not forget that Israeli forces destroyed the Haram al-Sharif Gate ... Let us not forget that Israeli extremists set fire to the Cave of the Patriarchs in Hebron and attacked praying people, and built a temple and a monument to glorify the despicable acts of these murderers.

In this case, the speaker Saad Abdullah Al-Saad (Saudi Arabia) used an aphoristic repetition that starts a sentence: ولنستنكر سوياً (let's not forget), as well as a positionally lexical repetition of one word in the middle and end of the same sentence: سجل (have in one's account). Inclusion of different types of repetition in the text: an anaphoristic one and repetition at the end and middle of a sentence, repetition of a word and a phrase, repetition at the level of both a paragraph and a sentence does not only make it possible to organise the text better, but also helps to achieve its expressivity. This figure of speech makes listeners pay attention to the speaker over and over again, as the grammatical form of the verb calls for joint action. The author lists the activities that the Israeli army is taking towards the Palestinians and Islamic sanctuaries [25], using repetition to introduce new information about the new Israeli executions. First it was violence, then it was the destruction of Islamic holy places. Each subsequent use of the repetition reveals the content of the first two.

من بينطيع أن يلوم الفلسطينيين إذا لم يصدقوا نوايا إسرائيل وحكومتها تجاه الحفاظ على سلامة المسجد

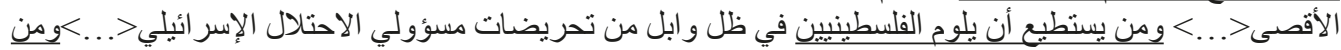

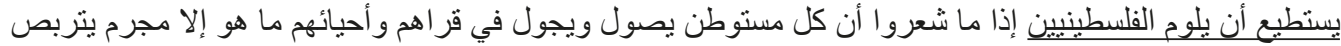

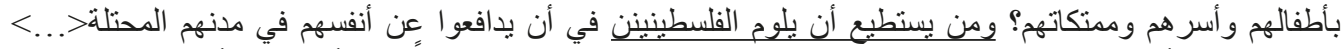
ومن يستطيع أن ينكر على الفلسطينيين حقهم في طلب الحماية الدولية دفاعاً عن أرضهم وأبنائهم ومقدساتهه؟

Who can really blame Palestinians of distrusting the intentions of Israel and its government to maintain and secure the Al-Aqsa Mosque or change its status quo? $<\ldots>$ Who can blame Palestinians of such reactions in the face of the Israeli occupation $<\ldots>$ Who can blame Palestinians of being afraid that settlers might enter their villages and settlements as criminals and start persecuting their children and families or encroaching on their property? Who can blame the Palestinians for trying to defend themselves in their occupied cities $\langle\ldots\rangle$ Who can deny the Palestinians' right to ask the international community to protect their land, their sons and their holy places?

A very emotional repetition من يسنطيع أن يلوم الفلسطينيين (who can blame the Palestinians) is used in this passage, which has an evaluative meaning. It also takes the form of a rhetorical question, which increases the impact on the audience, as it implies a certain type of intonation to which the audience responds. The author justifies the Palestinians for their behaviour towards Israel by pointing to the "atrocities" that "occupiers" may commit. At the end of the paragraph, the speaker slightly changes the elements of the repetitive word combination, using the verb "deny" (نكر) instead of "blame" (لام), in order to emphasize, by means of the effect of defeated expectancy, the fairness of the Palestinian demand for the world community to help them.

$$
\text { الإسر المملكة العربية السعودية تطالب المجتمع الدولي مجددا بأن يقول للاحتلال الإسر ائيلي كفي، وللظلم }
$$


The Kingdom of Saudi Arabia once again asks the international community to say to the Israeli occupation: "Enough", injustice made by Israel: "Enough", Israeli arrogance: "Enough"...

The lexical epistrophe in this passage makes it possible to achieve a statement's eurhythmy, which increases its expressivity. In addition, the connotative meaning of the repeated word expands the intensity of expression in the passage. In this way, the call for an end to Israeli policies in the Palestinian territories sounds like a slogan. This type of repetition makes the statement populist and has a strong influence on listeners.

As we can see, repetitions in Arab diplomatic communication can be of various kinds. Most often they take the form of an anaphora, which helps to organise the text. Frequently speakers use this figure of speech with other stylistic practices in order to draw the audience's attention to the issues under discussion as much as possible. In addition, it has been established that the prevailing majority of repetitions are used in the most emotional passages of speech. This allows us to say that repetition is the most powerful means of demonstration of expressivity in Arab diplomatic communication.

\section{Conclusion}

Speech expressivity in Arab diplomatic communication is an important element of the expressive means of a language. Not only does it make the speaker's statement brighter, but it also affects the listeners.

According to the analyzed sources, in the context of oral communication we observe deviations from the established norms of the diplomatic language. This is due to a mixture of different language styles: officialese, inherent in diplomatic correspondence, and publicistic, inherent in public speeches. In addition, when analysing the texts of speeches made by representatives of the diplomatic corps in the Arab States, we observe the interpenetration and mutual influence of different types of discourse, depending on the specific nature of the issue under discussion.

The greatest degree of expressivity was found at the syntactic and text levels. The abundance of repetitions in the form of anaphoras, epistrophes and symploces helps to draw listeners' attention to the most important parts of the performance. Repetitions of different types are often part of the convergence, which helps to achieve the maximum impact on the audience.

When analysing the main types of foregrounding - cohesion, convergence, the effect of defeated expectancy and repetition - It can be concluded that these techniques and practices are often used in Arab diplomatic communication and help to create expressivity at the syntactic and text levels. The function of foregrounding's types is to ensure that the text is structured and to highlight the most significant parts.

The most frequent repetitions in Arabic diplomatic discourse are those that keep the audience's attention around the issue under discussion. Repetitions help to rhythmise the speech, which also has an effect on the audience.

Commonly repetitions are part of the convergence - a type of foregrounding that is also quite often used by Arab representatives in their speeches. In this way, even greater expressivity of the text is achieved. Convergence strategy is in most cases used in the culmination passages of speech in order to ensure maximum impact on listeners and to convey the necessary information as clearly and precisely as possible. 
The effect of defeated expectancy is seldom found in the texts of speeches made by diplomats and politicians at UN platforms. This is due to the rare use of its elements: foreign vocabulary, neologisms, historisms, oxymorons etc. in diplomatic communication. Most often, this technique manifests itself on a semantic logical level when using first words with a positive connotation of meaning and then words with a negative connotation.

The strategies of expressivity used in public speeches addressing the current political situation in the Middle East sometimes reveal the speakers' biased and emotional attitude towards the problems in their region. For this reason, we see an abundance of emotionally evaluative vocabulary in the texts of speeches by Arab diplomats, where the negative evaluation of the current course of events prevails.

Furthermore, the Arab Permanent Representatives to the United Nations and other diplomatic and political actors are approaching to archetypical types (by using metaphors or phraseological units) that most cultures can recognize in order to achieve mutual understanding at the communication level.

\section{References}

1. Issers O.S. Communication strategies and tactics of Russian speech. Moscow, 2008. (In Russian)

2. Trabelsi X. Diplomatic correspondence and its characteristics. Ed. by J. Trabelsi. Aktualnye problemy gumanitarnyh i estestvennyh nauk, 2012, no. 8, pp. 151-155. (In Russian)

3. Haigadachnaya E. N. Expressive means of language in speech of politicians (on the material of texts of public speeches of W. Putin, T. Blair, J. Bush). PhD thesis. Rostov-on-Don, 2009. 206 p.

4. Alyoshina O.I. Language means of expression in political discourse. Sovremennye problemy prava, ekonomiki i upravleniia. 2015, no. 1. P. 84. (in Russian)

5. Issers O.S. Speech impact in terms of cognitive categories. Vestnik of Omsk University, 1999, vol. 1, pp. 74-79. Available at: https://omsu.ru/vestnik/articles/y1999-i1/a074/article.html 5 (accessed: 20.07.2020). (In Russian)

6. Panchenko V.A. To a question about concepts "expression" and "expressivity". Vestnik of Dnepropetrovsk University, 2014, p. 8. (In Russian)

7. Ozhegov S. I. Monolingual dictionary of Russian language: about 100000 words, terms and phraseological expressions. Moscow, 2014. 611 p. (In Russian)

8. Big encyclopedic dictionary. Ed. by I. Lapina. Moscow, 2003. 1019 p. (In Russian)

9. Ushakov D. N. Monolingual Dictionary of Modern Russian: 10,000 words. Moscow, 2010. 482 p. (In Russian)

10. Linguistic Encyclopedic Dictionary. Ed. by V.N. Yartseva. Moscow, 1990. 672 p. (In Russian)

11. Gnatiuk A.D. Means of Creation of Expression and its Intensification in Newspaper and Magazine Articles. Abstract of PhD thesis. Candidate of Science in Philology. Kiev, 1984. 3 p. (In Russian)

12. Guillaume G. Principles of Theoretical Linguistics. Moscow, 1992. 87 p. (In Russian)

13. Morgoeva L. B. Expressivity of Multilevel Units of Language. Vladikavkaz, 2009. 17 p. (In Russian)

14. Mishkurov E. N. Problems of improving the methods of teaching dialect languages in Arab countries. Moscow, 1976. 74 p. (In Russian)

15. Telitsyna E.L. To the Question of Distinguishing Concepts of Emotionality, Evaluativity and Expressivity. Vestnik of Yugra State University, 2016, no. 1, p. 81. (In Russian)

16. Chuhlantsev O.E. Functional and stylistic stratification and expressive and stylistic resources of the Arabic language. Abstract of $\mathrm{PhD}$ thesis. Candidate of Science in Philology. Moscow, 1994. 21 p. (In Russian)

17. Pavlova E. K. Lexical problems of global political discourse. Vestnik of Moscow University. Series 19. Linguistics and intercultural communication, 2005, no. 2, p. 216. (In Russian)

18. Pulenko I. P. Expressivity of syntax in public speeches. PhD thesis. Minsk, 1988. 12 p. (In Russian)

19. Arnold I. V. Stylistics of Modern English (decoding stylistics). Leningrad, 1981. 61 p. (In Russian) 
20. Aboulatta A. Security Council: $8105^{\text {th }}$ meeting: 16.11.2017. Available at: https://digitallibrary.un.org/ record/1319231? ln=ru (accessed: 25.09.2020). (In Arabic)

21. Lukanina M. V. Media text and convergence. Political linguistics, 2006, no. 20, p. 208. (In Russian)

22. Jaafari B. Security Council: $6627^{\text {th }}$ meeting: 04.10.2011. Available at: https://digitallibrary.un.org/record/712212? ln=ru (accessed: 25.09.2020). (In Arabic)

23. Al-Musharrakh J. Security Council: $7929^{\text {th }}$ meeting: 20.04.2017. Available at: https://digitallibrary. un.org/record/1288977? In=ru (accessed: 25.09.2020). (In Arabic)

24. Aboulatta A. Security Council: $7540^{\text {th }}$ meeting (Resumption 1): 22.10.2015. Available at: https://undocs.org/S/PV.7540(Resumption1) (accessed: 25.09.2020). (In Arabic)

25. Al-Saad S. A. Security Council: $7540^{\text {th }}$ meeting: 22.10.2015. Available at: https://digitallibrary.un.org/ record/808258? $\ln =\mathrm{ru}$ (accessed: 25.09.2020). (In Arabic)

Received: September 28, 2020 Accepted: December 28, 2020

Authors' information:

Enesh K.Akhmatshina — PhD in Political Science; e.akhmatshina@spbu.ru

Kseniya Yu. Demidova — demidova.kseniya2013@yandex.ru

Aleksei Yu. Bykov — PhD in Political Science; a.y.bykov@spbu.ru

\title{
Приемы речевой экспрессии в арабской дипломатической коммуникации
}

\author{
Э. К. Ахматиина ${ }^{1}$ К. Ю. Демидова ${ }^{2}$, А. Ю. Бъков ${ }^{1}$
}

${ }^{1}$ Санкт-Петербургский государственный университет,

Российская Федерация, 199034, Санкт-Петербург, Университетская наб., 7-9

${ }^{2}$ Национальный исследовательский университет «Высшая школа экономики»,

Российская Федерация, 190008, Санкт-Петербург, ул. Союза печатников, 16

Для цитирования: Akhmatshina E.K., Demidova K. Yu., Bykov A. Yu. Techniques and Practices of Speech Expression in Arab Diplomatic Communication // Вестник Санкт-Петербургского университета. Востоковедение и африканистика. 2021. Т. 13. Вып. 1. С. 103-118.

https://doi.org/10.21638/spbu13.2021.107

В настоящей статье анализируются средства речевой экспрессии в арабской дипломатической коммуникации на примере выступлений арабских представителей дипломатического корпуса и политических деятелей на различных площадках ООН. Материалом для исследования послужили оригинальные тексты выступлений постоянных представителей арабских стран при ООН, затрагивающих ситуацию на Ближнем Востоке. Временные рамки охватывают период с 2011 по 2018 гг. Мультимедийные ресурсы ООН являются одной из крупнейших площадок для дипломатического диалога, открытой широкой общественности. Ввиду интенсификации отношений России и арабских стран возникает необходимость выявление специфики арабской дипломатической коммуникации, так как спикер в своих выступлениях призван выражать не собственное отношение и оценку, а отношение государства, которое он представляет. При анализе текстов выступлений представителей дипломатического корпуса в целом мы наблюдаем взаимопроникновение и взаимовлияние нескольких типов языковых стилей: официально-делового, присущего дипломатической переписке, и публицистического, присущего публичным выступлениям, в зависимости от специфики обсуждаемого вопроса. Смешение стилей, несомненно, отражается как на лексической, так и на синтаксической нагрузках текстов. В свою очередь, арабские спикеры в силу сложных условий сложившейся политической обстановки на Ближнем Востоке не могут оставаться 
эмоционально равнодушными к проблемам их региона. В этой связи мы фиксируем в выступлениях арабских дипломатов не только регулярное отступление от принятых в дипломатии речевых стандартов (к примеру, обилие эмоционально-оценочной лексики в текстах выступлений), но и особую стратегию построения текстов, способствующую созданию определенного эффекта на слушателей и оппонентов, - экспрессию. Среди наиболее часто используемых приемов речевой экспрессии мы выделили повтор, сцепление, конвергенцию и прием обманутого ожидания. Посредством анализа экспрессивного синтаксиса мы изучили специфику использования указанных приемов речевой экспрессивности на уровне узуально-клишированного арабского текста и выделили особенности применения данной речевой стратегии в языке арабской дипломатии.

Ключевые слова: арабский литературный язык, язык арабской дипломатии, речевая экспрессия.

Статья поступила в редакцию 28 сентября 2020 г., рекомендована к печати 28 декабря 2020 г.

Контактная информация:

Ахматшина Энеш Курбансейидовна - канд. полит. наук; e.akhmatshina@spbu.ru

Демидова Ксения Юрьевна - demidova.kseniya2013@yandex.ru

Быюков Алексей Юрьевич - канд. полит. наук; a.y.bykov@spbu.ru 